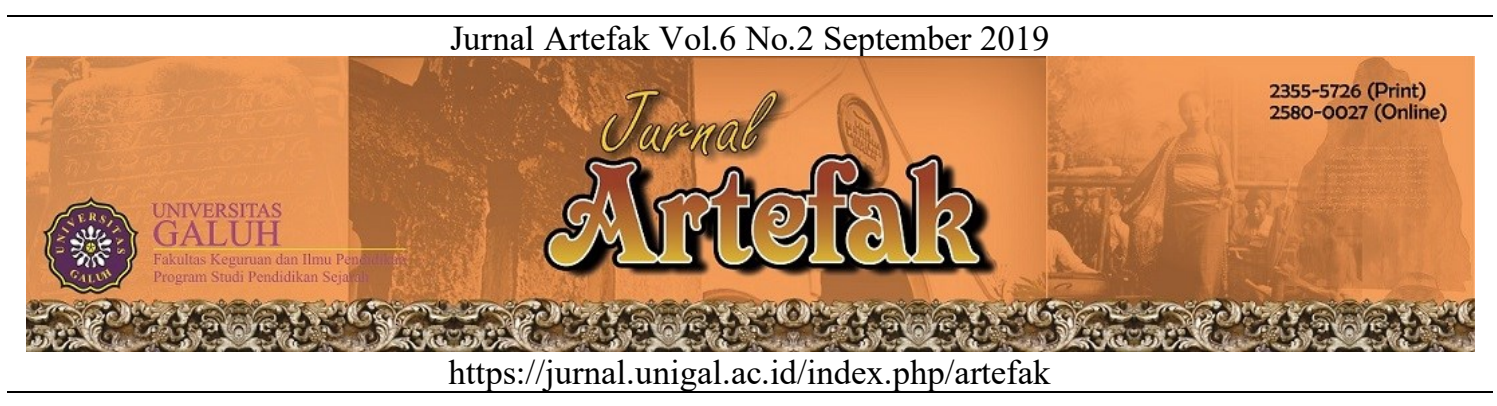

\title{
TRADISI UPACARA PERKAWINAN ADAT SUNDA (Tinjauan Sejarah dan Budaya di Kabupaten Kuningan)
}

\author{
Agus Gunawan \\ Universitas Kuningan, Indonesia \\ Jl. Cut Nyak Dhien No.36 A, Cijoho, Kec. Kuningan, Kabupaten Kuningan, Jawa Barat \\ Email: agusgunawan1967@yahoo.com \\ Sejarah Artikel: Diterima 19-8-2019, Disetujui 30-8-2019, Dipublikasikan 7-9-2019
}

\begin{abstract}
Abstrak
Perkawinan adalah peristiwa yang sangat penting, karena menyangkut tata nilai kehidupan manusia. Oleh sebab itu perkawinan merupakan tugas suci (sakral) bagi manusia untuk mengembangkan keturunan yang baik dan berguna bagi masyarakat luas. Hal ini tersirat dalam tata cara upacara perkawinan. Semua kegiatan, termasuk segala perlengkapan upacara adat merupakan simbol yang mempunyai makna bagi pelaku upacara. Di samping itu pelaku memohon kepada Tuhan agar semua permohonan dapat dikabulkan. Problem penelitian disini adalah mengapa masyarakat di Kabupaten Kuningan mayoritas beragama Islam, tetapi dalam setiap upacaranya masih ada yang menggunakan berbagai bentuk sesaji. Secara normatif, Islam mengajarkan bahwa hanya kepada Tuhanlah orang menyandarkan kebutuhannya, tidak melalui sesaji. Manusia bisa mengajukan permohonan secara langsung kepada Tuhan. Upacara perkawinan masyarakat di Kabupaten Kuningan diselenggarakan dengan cara sederhana. Upacara perkawinan ini ada beberapa tahapan, yaitu, pra perkawinan, perkawinan dan sesudah perkawinan. Pra perkawinan, dilakukan sebelum aqad nikah, seperti melamar, seserahan, dan ngeuyeuk seureh. Pelaksanaan perkawinan, seperti aqad nikah dan sungkem. Sesudah perkawinan, dilakukan setelah aqad nikah, seperti upacara sawer, nincak endog (telur), buka pintu, dan munjungan.
\end{abstract}

Kata Kunci: Tradisi Upacara dan Perkawinan Adat Sunda

\begin{abstract}
Marriage is a very important event because it involves the values of human life. Therefore marriage is a sacred duty (sacred) for humans to develop offspring that are good and useful for the wider community. This is implied in the marriage ceremony procedures. All activities, including all ceremonial equipment are symbols that have meaning for the performers of the ceremony. In addition, the offender pleads to God so that all requests can be granted. The research problem here is why the majority of people in Kuningan Regency are Muslim, but in each ceremony there are still those who use various forms of offerings. Normatively, Islam teaches that it is only to God that people rely on their needs, not through offerings. Humans can submit requests directly to God. The community wedding ceremony in Kuningan District was held in a simple way. This marriage ceremony has several stages, namely, pre-marriage, marriage and after marriage. Pre-marriage carried out before aqad nikah, such as applying for marriage and making love. The implementation of marriage, such as marriage aqad and sungkem. After marriage, it is done after aqad marriage, such as sawer ceremony, nincak endog (eggs), open the door, and munjungan.
\end{abstract}

Keyword: Sundanese Traditional Ceremony and Marriage Traditions 
Manusia merupakan makhluk yang berbudaya, melalui akalnya manusia berpikir sehingga mampu menciptakan berbagai kebudayaan yang pada gilirannya tumbuh dan berkembang dalam suatu masyarakat. Kebudayaan dapat mengalami akulturasi bentuk, antara yang baru dengan yang sudah ada, sehingga bentuk dan coraknya bisa pula dipengaruhi oleh unsur kepercayaan yang bermacam-macam, seperti animisme, dinamisme, perkembangan agama Islam serta Hindu -Budha. Kebudayaan diartikan sebagai upaya masyarakat untuk terus menerus secara dialektis menjawab setiap tantangan yang dihadapkan dengan menciptakan berbagai prasarana dan sarana. Kebudayaan mempunyai fungsi yang sangat besar bagi manusia karena setiap manusia dalam masyarakat selalu menemukan kebiasaan baik atau buruk bagi dirinya. Kebiasaan yang baik akan diakui dan dilaksanakan oleh orang lain yang kemudian dijadikan dasar bagi hubungan antara orang-orang tertentu, sehingga tindakan itu menimbulkan norma atau kaidah Norma atau kaidah itu disebut juga dengan adat istiadat (Musa Asy'ari, 1992: 95).

Mengenai adat istiadat dapat pula menyentuh penyelenggara upacara adat dan aktivitas ritual yang dianggap sangat mempunyai arti bagi warga pendukungnya, selain sebagai penghormatan terhadap leluhur dan rasa syukur terhadap Tuhan Yang Maha Kuasa, juga sebagai sarana sosialisasi dan pengukuhan nilai-nilai budaya yang sudah ada dan berlaku dalam kehidupan masyarakat sehari-hari. Demikian pula halnya yang terjadi di wilayah Kabupaten Kuningan, di sana muncul suatu bentuk upacara adat yang dianggap sakral dalam menggunakan simbolsimbol sehingga menarik untuk diteliti yaitu upacara perkawinan adat Sunda. Perkawinan menurut istilah ilmu Fiqih dipakai perkataan "nikah" dan "jiwaz". Secara etimologi, "nikah" mempunyai arti sebenarnya dan arti kiasan. Arti sebenarnya dari "nikah", ialah menghimpit, menindih atau berkumpul, sedang arti kiasannya ialah setubuh, atau mengadakan perjanjian pernikahan (Kamal Mukhtar, 1993: 1).

Sementara itu perkawinan adalah peristiwa yang sangat penting, karena menyangkut tata nilai kehidupan manusia, oleh sebab itu perkawinan merupakan tugas suci bagi manusia untuk mengembangkan keturunan yang baik dan berguna bagi masyarakat luas. Hal ini tersirat dalam tata cara upacara perkawinan. Semua kegiatan, termasuk segala perlengkapan upacara adat merupakan simbol yang mempunyai makna bagi pelaku upacara. Di samping itu pelaku memohon kepada Tuhan Yang Maha Esa agar semua permohonan dapat dikabulkan. (Thomas Wiyasa Bratawidjaja, 1990: 9).

Simbol merupakan salah satu inti dari kebudayaan dan menjadi pertanda dari tindakan manusia selalu ada dan masuk dalam segala unsur kehidupan. Simbol-simbol yang berupa benda-benda, sebenarnya terlepas dari tindakan manusia. Sebaliknya, tindakan manusia harus selalu mempergunakan simbolsimbol sebagai media penghantar dalam komunikasi antar sesama. Penggunaan simbol dalam wujud budaya ternyata dilaksanakan dengan penuh kesadaran, pemahaman, dan penghayatan yang tinggi, yang dianut secara tradisional dari satu generasi ke generasi berikutnya. (Budiono Herusatoto, 2000: 18).

Menurut kepercayaan masyarakat wilayah Kabupaten Kuningan, menjalankan adat istiadat warisan nenek moyang berarti menghormati para leluhur mereka. Segala sesuatu yang datangnya bukan dari ajaran leluhur dan sesuatu yang tidak dilakukan leluhurnya dianggap sesuatu yang tabu. Ini menjadi aturan tak tertulis yang harus dijalani. Jika tidak dijalani mereka dianggap melanggar adat, dan diyakini akan menimbulkan malapetaka. Upacara perkawinan dalam masyarakat di Kabupaten Kuningan tidak serampangan bisa digelar, banyak persiapan yang harus dijalani. Mulai dari merencanakan jadwal pelaksanaan berdasarkan perhitungan waktu yang tepat untuk menggelar hajat, sampai pada prosesi pelaksanaan ritualnya. Bulan Sapar dan bulan Ramadhan merupakan bulan larangan (pamali) untuk menyelenggarakan acara-acara penting, seperti perkawinan, khitanan, membangun rumah dan upacara adat. Hal ini dikarenakan bulan tersebut bertepatan dengan upacara menyepi. (Heni Fajria Rif'ati, 2002: 170).

Upacara perkawinan yang diselenggarakan di wilayah Kabupaten Kuningan sangat sederhana, pelakunya yaitu dari petugas KUA setempat, kuncen (Amil), kedua mempelai, orang tua mempelai, kerabat dekat mempelai. Tahapan-tahapan dalam upacara perkawinan yaitu, pra perkawinan 
yang dilakukan sebelum aqad nikah seperti ngalamar, Ngeuyeuk seureuh dan seserahan. Pelaksanaan perkawinan atau acara inti, seperti aqad nikah dan sungkem. Sesudah perkawinan, dilakukan setelah aqad nikah, seperti upacara sawer, nincak endog, buka pintu, ngariung dan munjungan. Dalam perkawinan masyarakat di Kabupaten Kuningan, ada beberapa upacara yang berbeda dengan perkawinan pada umumnya dan menarik untuk diteliti.

Pra perkawinan, yang pertama melamar, menyatakan permintaan untuk perjodohan dari seorang laki-laki pada seorang perempuan atau sebaliknya dengan perantara orang yang dipercayai. Kedua, upacara ngeuyeuk seureuh, upacara ini biasanya dilakukan sehari sebelum perkawinan. Ketiga, upacara seserahan dalam upacara ini orang tua calon pengantin pria menyerahkan putranya kepada orang tua calon pengantin wanita sambil membawa barang-barang keperluan calon pengantin wanita. Perkawinan inti dari upacara yaitu aqad nikah, dilakukan dengan ijab kabul yang disaksikan oleh dua orang saksi. Terjadinya proses ijab-kabul ini biasa disebut dirapalan. Bagi masyarakat di wilayah Kabupaten Kuningan yang beragama Islam, maka perkawinannya dilaksanakan di depan penghulu dan kemudian dicatat oleh pegawai KUA setempat. Sesudah perkawinan ada beberapa ritual lain yang dilaksanakan yaitu, pertama upacara sawer dilakukan setelah akad nikah, pasangan pengantin dibawa ke tempat panyaweran atau tempat terbuka. Kemudian panyawer melantunkan syair sawer, sambil menabur beras yang bercampur irisan kunir dan uang receh ke penonton. Kedua, upacara nincak endog. Endog (telur) di simpan diatas golodog dan mempelai laki-laki menginjaknya. Kemudian mempelai perempuan mencuci kaki mempelai laki-laki dengan air kendi. Setelah itu mempelai perempuan masuk ke dalam rumah, sedangkan laki-laki berdiri di muka pintu untuk melaksanakan upacara ketiga yaitu buka pintu. Dalam upacara buka pintu terjadi tanya jawab antara kedua mempelai yang diwakili oleh masing-masing pendampingnya dengan cara dilagukan. Keempat, upacara ngariung sambil menarik bakakak hayam, saling makan sesuap nasi kuning dan minum bersama atau disebut huap lingkung. Yang terakhir yaitu munjungan atau sungkem, kedua mempelai mengunjungi kedua orang tua mereka, kerabat dekat dan sesepuh.

\section{METODE PENELITIAN}

Penelitian ini menggunakan metode sejarah (historis), yaitu suatu cara yang ditempuh dalam mempelajari suatu peristiwa sejarah. Atau, penelitian yang bertugas mendeskripsikan gejala, tetapi bukan yang terjadi pada waktu penelitian dilakukan. Menurut Ismaun (2005: 35) metode historiografi merupakan proses untuk menguji dan mengkaji kebenaran rekaman dan peninggalan-peninggalan masa lampau dengan menganalisis secara kritis bukti-bukti dan data-data yang ada sehingga menjadi penyajian yang dapat dipercaya. Menurut Kuntowijoyo (2005: 91) metode dalam penelitian sejarah mempunyai lima tahapan dalam proses penelitiannya, yaitu:

1) Pemilihan topik. Topik dipilih berdasarkan: (1) kedekatan emosional, (2) kedekatan intelektual, setelah topik ditemukan, langkah berikutnya (3) membuat rencana penelitian.

2) Pengumpulan sumber. Sumber (sumber sejarah disebut juga data sejarah; bahasa Inggris datum) yang dikumpulkan harus sesuai dengan jenis sejarah yang akan ditulis. Sumber itu, menurut bahannya dibagi menjadi dua: tertulis dan tidak tertulis, atau dokumen dan artefak.

3) Verifikasi. Setelah diketahui secara persis topik yang diajukan dan sumber sejarah sudah terkumpul, tahap berikutnya adalah verifikasi, kritik sejarah, atau keabsahan sumber. Verifikasi ada dua macam: autensitas atau keaslian sumber, atau kritik ekstern, dan kredibilitas, atau kebiasaan dipercayai, atau kritik intern.

4) Interpretasi. Interpretasi atau penafsiran sering disebut sebagai biang subjektivitas. Sebagian itu benar, tapi sebagian salah. Benar, karena penafsiran sejarawan, data tidak bisa berbicara. Sejarawan yang jujur, akan mencantumkan data dan keterangan dari mana data itu diperoleh. Tahap interpretasi, paling tidak meliputi analisis dan sintesis.

5) Penulisan. Dalam penulisan sejarah, aspek kronologi sangat penting. Penyajian penelitian dalam bentuk tulisan mempunyai tiga bagian: (1) Pengantar, (2) 
Hasil Penelitian dan (3) Simpulan.

Dengan menempuh kelima langkah diatas, dapat dipastikan akan diperoleh hasil penelitian yang diharapkan. Tentunya langkah demi langkah harus dikuasai benar agar tidak terjadi kekeliruan yang tidak diharapkan sehingga berakibat pada kurang tercapainya tujuan penelitian ini.

\section{HASIL PENELITIAN DAN PEMBAHASAN}

Prosesi pelaksanaan upacara perkawinan adat sunda pada masyarakat di wilayah Kabupaten Kuningan

Dalam perkembangan zaman yang semakin modern, upacara tradisional sebagai wahana budaya leluhur bisa dikatakan masih memegang peranan penting dalam kehidupan masyarakat. Upacara tradisional yang memiliki makna filosofis sampai sekarang masih dipatuhi oleh masyarakat pendukungnya. Hal ini disebabkan masyarakat merasa takut akan mengalami hal - hal yang tidak diinginkan jika tidak melaksanakan upacara tradisional. Salah satu unsur budaya yang masih diakui keberadaannya dan dianggap sebagai warisan budaya yang penting dalam perjalanan hidup setiap orang adalah upacara perkawinan adat. Perkawinan dalam bahasa Arabnya disebut nikah. Kedua konsep tersebut dalam kehidupan sehari - hari selalu disamakan pemahamannya. Menurut K.H. Ahmad Azhar Basyir dalam bukunya yang berjudul Hukum Perkawinan Islam (1999:4), perkawinan adalah suatu aqad atau perikatan untuk menghalalkan hubungan kelamin antara laki - laki dan perempuan dalam rangka mewujudkan kebahagiaan hidup keluarga yang diliputi rasa ketentraman serta kasih sayang dengan cara yang diajarkan oleh agama Islam.

Berkeluarga itu hukumnya sunnah Rosul mengikuti Nabi Muhammad SAW, seperti firman Allah dalam surat Ar-Ra'du ayat 38 yang artinya "dan sesungguhnya Kami telah mengutus beberapa Rasul sebelum kamu dan Kami memberikan kepada mereka istriistri dan keturunan......" Salah satu upacara perkawinan adat Sunda adalah upacara perkawinan pada masyarakat Kabupaten Kuningan. Upacara perkawinan adat di Kabupaten Kuningan lebih didominasi oleh nilai - nilai dan ajaran agama yang dianut yakni agama Islam, karena walaupun dalam prosesi perkawinan yang diwariskan para leluhur, namun secara esensial diwarnai dengan ajaran - ajaran Islam. Oleh karena itu, perkawinan yang ada di Kabupaten Kuningan merupakan perpaduan antara nilai istiadat masyarakat, ajaran agama dan undang undang yang telah ditetapkan pemerintah Indonesia.

Upacara perkawinan di berbagai daerah, mempunyai keunikan dan keragaman yang berbeda - beda, baik dari segi ritual perkawinan, prosesi, maupun alat - alat yang digunakan dalam upacara perkawinan adat tersebut. Hal ini menggambarkan adanya perbedaan pandangan, pemahaman, dan kepercayaan yang dianut oleh berbagai daerah yang ada di Indonesia. Penyelenggaraan upacara perkawinan di lingkungan masyarakat Sunda ada perbedaan dengan pelaksanaan perkawinan di kalangan masyarakat Kabupaten Kuningan. Upacara perkawinan di Kabupaten Kuningan diselenggarakan secara sederhana. Mereka yang menghadiri upacara perkawinan tersebut terbatas pada lingkungan keluarga terdekat, baik dari pihak mempelai wanita maupun pihak mempelai laki - laki. Ada yang unik dalam upacara adat perkawinan di masyarakat Desa Lebakherang Kecamatan Ciwaru Kabupaten Kuningan ciri khas yaitu seperti adat boboroloan salah satunya, boboroloan adalah adat yang dilakukan oleh kedua mempelai pengantin salah satunya adalah anak bungsu atau pun keduanya anak bungsu.Boboroloan ini merupakan pengumpulan uang yang di tempatan dalam wadah yang cukup besar, kemudian kedua mempelai berkeliling kesanak saudara bermaksud sanak sodara memberikan uang dan mengisi pada wadah yang dibawa oleh kedua mempelai setelah pengumpulan uang tersebut kemudian mereka duduk kembali pada kursi pengantin. (Wawancara dengan Tarmudin, tanggal 25 April 2019)

Dalam upacara perkawinan di Kabupaten Kuningan terkandung nilai - nilai dan norma - norma yang mempunyai fungsi dalam mengatur serta mengarahkan tingkah laku setiap anggota masyarakat. Dengan demikian, tata upacara perkawinan adat Sunda di Kabupaten Kuningan merupakan perpaduan dari unsur sifat, karakteristik, kepercayaan dan agama, yang kesemuanya saling menopang satu sama lain. Setiap upacara, baik sebelum 
waktu pelaksanaan maupun sesudah perkawinan mengandung unsur tujuan, tempat, waktu, alat - alat dan jalannya upacara.

\section{Sebelum Upacara Perkawinan}

Tahap upacara tersebut dilaksanakan sesuai dengan ekonomi dan situasi yang ada pada waktu, namun tidak boleh menyimpang dari tata cara pokok adat istiadat Sunda. Tahap upacara perkawinan di beberapa desa Kabupaten Kuningan, secara jelas diuraikan sebagai berikut:

a. Melamar atau Meminang

Melamar adalah satu tahapan yang menunjukkan (menyatakan) permintaan untuk perjodohan dari seorang laki - laki pada seorang perempuan dengan perantara seseorang yang dipercayai. Tujuan lamaran ini adalah untuk menanyakan kepada kedua orang tua perempuan, apakah anak yang dimaksud masih sendiri atau sudah ada yang punya. Dalam Islam pinangan disunnahkan dan dianjurkan kepada manusia. Di kalangan masyarakat Kabupaten Kuningan, bila akan menikahkan anaknya, orang tua pria perlu berkunjung ke rumah orang tua wanita yang menjadi pilihan anaknya. Hal ini perlu dilakukan dalam rangka mendapatkan keterangan lebih jelas mengenai data pribadi wanita yang dimaksud, seperti apakah wanita itu, sudah mempunyai pacar atau belum dan juga hal lain yang dipandang perlu dalam memperdalam pengetahuan terhadap calon pasangan yang akan menjadi teman hidup anaknya, bagi masyarakat Kabupaten Kuningan tahapan ini disebut juga dengan nanyaan. Apabila wanita yang dimaksud belum mempunyai pacar atau tunangan dan orang tuanya juga setuju dengan pria yang diajukan, maka terjadilah perembukan yang dinamakan Neundeun omong. Sejak peristiwa ini, maka kedua belah pihak mulai dengan saling kunjung mengunjungi, kadang - kadang bila ada rejeki, mereka saling berkirim makanan atau lainnya, sehingga hal itu akan menimbulkan hubungan yang erat dari kedua belah pihak.

\section{b. Ngeuyeuk seureuh}

Upacara ngeuyeuk seureuh ini biasanya diselenggarakan pada malam hari sebelum akad nikah di rumah orang tua calon pengantin wanita. Pelaksanaannya dipimpin oleh seseorang yang benar benar tahu tentang upacara ini, yang disebut pengeuyeuk. Sedangkan kuncen bertugas membakar kemenyan pada waktu upacara serta membaca do'a setelah upacara selesai. Upacara ngeuyeuk seureuh ini dilakukan pada malam hari. Pada masyarakat Sunda umumnya, upacara ini tidak boleh dihadiri oleh sembarang orang, tetapi beberapa masyarakat desa di Kabupaten Kuningan berbeda, para pendukung dalam upacara ini boleh siapa saja dan tidak ada larangan. Namun karena upacara ini dilakukan malam hari, jarang sekali anak - anak kecil atau yang dianggap belum berumur ikut menonton.

Prosesi dalam upacara ini adalah kedua mempelai mempersiapkan peralatan pengantin yang akan dipakai besok, seperti pakaian pengantin laki - laki dan wanita, sepatu, kosmetik, tikar, peralatan sawer dan lain - lain. Semua barang - barang yang sudah disiapkan tadi ditumpuk jadi satu dalam ayakan (alat penyaring). Tumpukan paling bawah sendiri biasanya ditaruh seureuh bertangkai. Setelah semua peralatan lengkap, ayakan yang berisi perlengkapan pengantin diikat/ditutupi dengan kain, lalu diangkat oleh pasangan pengantin, untuk ditaruh diatas kepulan asap kemenyan sambil dibacakan sambil dibacakan do'a oleh kuncen. Pada saat memegang dan mengangkat perlengkapan upacara ngeuyeuk seureuh ini tidak boleh lepas, keduanya harus saling bekerja sama maksud dari acara ini adalah bahwa dalam hidup rumah tangga harus selalu tolong menolong antara sesama. Pembacaan do'a selesai, maka selesai pula upacara ngeuyeuk seureuh.

\section{c. Upacara Seserahan}

Seserahan artinya menyerahkan atau memasrahkan. Upacara ini biasanya berlangsung sebelum aqad nikah dilaksanakan. Menurut Hilman Hadi (1990: 131) dalam upacara ini orang tua calon pengantin pria menyerahkan putranya kepada orang tua pengantin putri untuk dikawinkan dengan putrinya sambil 
membawa barang - barang keperluan calon pengantin. Hal semacam ini sebenarnya bukan menjadi kewajiban setiap pengantin pria, sebagian calon pengantin pria cukup menyerahkan uang saja. Jumlah dan nilai barang - barang yang dibawa/diserahkan, tergantung pada kemampuan pihak laki laki yang juga disepakati pihak perempuan. Makin tinggi nilainya tentu makin membahagiakan hati perempuan.

Biasanya barang - barang yang dibawa pada saat seserahan adalah berupa uang, pakaian perempuan, perhiasan perhiasan seperti gelang, kalung dan lain lain, alat - alat kecantikan wanita. Bahkan ada diantaranya di salah satu desa di Kabupaten Kuningan ditambah juga dengan membawa binatang ternak seperti ayam, kambing, dan ada pula yang menambahnya dengan alat - alat rumah tangga, alat - alat dapur. Semua barang barang itu dimaksudkan untuk dipakai nanti bilamana mereka berumahtangga sendiri setelah kawin. Barang - barang yang diserahkan ini biasanya atas dasar persetujuan kedua belah pihak sewaktu berembuk upacara melamar.

\section{Upacara Pada Saat Perkawinan}

Upacara perkawinan lazimnya dilangsungkan di rumah orang tua calon pengantin wanita. Pada hari perkawinan pria diantar dengan iring - iringan dari suatu tempat yang telah ditentukan menuju ke rumah calon pengantin wanita. Dalam iring iringan tersebut biasanya pengantin pria dipayungi. Bila pengantin pria berdekatan rumah dengan pengantin wanita, maka calon pengantin pria langsung menuju calon pengantin wanita, ciri khas pakaiannya memakai sinjang dan singer (Wawancara dengan Leni Isnayati, tanggal 12 Mei 2019). Adapun tahap pelaksanaan perkawinan di Kabupaten Kuningan sebagai berikut:

\section{a. Akad Nikah}

Upacara perkawinan di kalangan masyarakat Kabupaten Kuningan prinsipnya tidak banyak berbeda dengan anggota masyarakat lainnya yang tinggal di luar Kabupaten Kuningan. Artinya bahwa sebelum kedua mempelai melangsungkan akad nikah, mereka lebih dulu harus memenuhi persyaratan administrasi. Sebagaimana tercermin dalam salah satu falsafah hidup mereka sehari - hari. "Parentah gancang lakonan, panyaur geura temonan, panundut gancang caosan". Maksudnya adalah perintah dan permintaan dari aparat pemerintah harus segera dilaksanakan. Upacara akad nikah di setiap daerah mempunyai perbedaan dalam setiap prosesnya, seperti ritual akad nikah pada masyarakat Jawa berbeda dengan masyarakat Sunda dan seterusnya. Hal ini disebabkan perbedaan pemahaman yang di dalamnya menyangkut perbedaan adat istiadat yang berlaku di suatu daerah tertentu.

Proses akad nikah merupakan ritual yang sangat sakral, sebab mereka menganggap ritual - ritual yang ada dalam akad nikah harus dijunjung tinggi kebenarannya, baik dalam tata caranya maupun individu yang melakukannya. Dalam hal ini kedua belah pihak mempelai pria dan wanita harus mempersiapkan terlebih dahulu dengan matang, baik dalam menentukan tanggal, hari maupun alat alat yang akan digunakan pada waktu proses akad nikah. Dengan kesiapan yang matang prosesi akad nikah akan berjalan baik.

Upacara akad nikah di Kabupaten Kuningan dilakukan dengan ijab - kabul yang disaksikan oleh dua orang saksi. Ijab artinya pernyataan dari ayah mempelai wanita yang bertindak sebagai wali. Namun jika ayahnya berhalangan tidak bisa hadir karena sakit atau sudah meninggal, peran ayah bisa digantikan oleh orang yang diberi kuasa untuk bertindak sebagai wali. Setelah ijab diucapkan, segera disusul dengan ucapan kabul oleh mempelai laki - laki sebagai tanda penerimaan. Sehingga dengan selesainya ijab-kabul tersebut, kedua mempelai sudah sah menjadi suami istri. Terjadinya proses ijab-kabul tersebut oleh masyarakat Kabupaten Kuningan disebut dirapalan.

Masyarakat Kabupaten Kuningan semuanya beragama Islam, maka dalam upacara perkawinan adat di kampung ini selain ada ritual yang berasal dari adat setempat juga disesuaikan dengan ketentuan syari'at agama Islam. Dalam hal ini menurut peraturan agama, perkawinan dianggap sah apabila pada waktu akad nikah dihadiri oleh kedua mempelai, wali, 
saksi (minimal 2 orang), penghulu atau petugas dari Kantor Urusan Agama, dan mas kawin.

\section{b. Sungkem}

Upacara ini merupakan upacara adat yang sangat berkesan. Upacara ini akan menimbulkan perasaan terharu yang luar biasa, baik bagi kedua mempelai maupun bagi hadirin yang ikut menyaksikannya. Dalam upacara ini mula - mula pengantin wanita sungkem kepada ibunya, kemudian bertukar, pengantin laki - laki kepada mertua perempuan dan pengantin wanita sungkem kepada ayahnya, begitu seterusnya kepada orang tua pihak laki laki dengan cara yang sama.

Adapun arti sungkem yang dilakukan oleh kedua pengantin ke hadapan orang tua serta keluarga yang lebih tua (pinisepuh) dari kedua belah pihak, menunjukkan tanda bakti dan rasa terima kasih atas bimbingan dari lahir sampai perkawinan. Selain itu kedua pengantin mohon do'a restu dalam membangun kehidupan rumah tangga yang baru agar selalu mendapatkan berkah dan rahmat Tuhan.

\section{Upacara Setelah Perkawinan}

Walaupun pasangan pengantin tersebut sudah dinyatakan sah sebagai suami istri, namun karena mereka merupakan bagian dari masyarakat adat, maka upacara perkawinannya masih harus dilanjutkan dengan prosesi berikutnya yang didasarkan pada adat dan tradisi leluhurnya.

a. Upacara Sawer

Upacara sawer dilakukan setelah selesai akad nikah, pasangan pengantin duduk di kursi yang ditaruh di depan rumah mempelai wanita yang disaksikan ratusan pasang mata. Tempat yang digunakan untuk upacara sawer merupakan tempat terbuka yang biasa disebut tempat penyaweran. Pasangan pengantin tersebut didampingi oleh seorang pemegang payung dan didepannya berdiri juru sawer atau biasa disebut penyawer. Juru sawer ini umumnya kaum wanita.

Upacara sawer diawali dengan mengucapkan ijab kabul oleh penyawer, kemudian dilanjutkan dengan melantunkan syair/puisi sawer. Puisi sawer adalah puisi yang biasa dilagukan pada waktu upacara sawer seperti pada waktu upacara khitanan dan perkawinan. Kata sawer mengandung arti "tabur atau sebar". Setelah melantunkan satu bait syair sawer, penyawer menyelinginya dengan menaburkan beras, irisan kunir, permen, uang logam dan bermacam - macam bunga rampai yang disimpan di dalam baskom ke atas payung atau ke arah pengantin. Sehingga dalam waktu bersamaan, anak anak yang bergerombol di belakang pengantin saling berebut memungut uang sawer dan permen sebanyak - banyaknya. Begitu seterusnya sampai isi yang di baskom habis terkuras.

Adapun sajak atau syair yang dipakai oleh masyarakat Kabupaten Kuningan dalam upacara sawer adalah memakai sekar macapat yaitu dandanggula, kinanti, sinom, asmarandana, dan lain - lain. Syair sawer merupakan tembang atau lagu yang dinyanyikan oleh juru sawer setelah ijab qabul dalam prosesi perkawinan adat Sunda. Syair sawer biasnya terdiri dari pendahuluan atau pembukaan, isi (nasihat kepada pengantin wanita dan pengantin lelaki), dan penutup.

\section{b. Upacara Nincak Endog (injak telur)}

Usai upacara sawer dilanjutkan dengan upacara nincak endog. Kedua pengantin dipersilahkan berdiri menuju tangga rumah. Pengantin pria berdiri di bawah tangga dan pengantin wanita berdiri di anak tangga rumah yang lebih tinggi sambil membawa kendi dan saling berhadapan muka. Dalam pelaksanaanya pengantin pria langsung menginjak endog (telur) yang ditaruh di atas papan ijakan. Telur itu harus pecah dengan sekali menginjaknya. Kemudian mempelai perempuan mencuci kaki mempelai laki laki dengan air kendi sambil diterangi oleh lilin/Pelita, dan kendi yang kosong langsung dihempaskan ke tanah hingga hancur. Setelah itu mempelai perempuan masuk ke dalam rumah, sedangkan mempelai laki - laki berdiri di muka pintu untuk melaksanakan upacara buka pintu.

\section{c. Upacara Muka Panto (Buka Pintu) \\ Upacara muka panto merupakan suatu percakapan atau proses tanya jawab}


antara pengantin pria yang berada di luar rumah dengan pengantin wanita yang berada di dalam rumah. Proses tanya jawab itu dilaksanakan oleh kedua mempelai sendiri, tetapi pada umumnya diwakili oleh masing - masing pendampingnya atau ahlinya yaitu juru mamaos dengan cara dilagukan. Hal ini karena syair merupakan tanya jawab dan mengandung Petuah petuah atau nasihat - nasihat. (Lihat lampiran syair buka pintu).

Upacara muka panto dimulai dengan ketukan pintu tiga kali oleh pengantin pria atau pendampingnya, sebagai pembuka dalam percakapan ini biasanya mempelai laki - laki mengucapkan salam 'Assalamu'alaikum' yang kemudian dijawab oleh mempelai perempuan 'Wa'alaikum salam'. Maka selanjutnya terjadilah tanya jawab kedua mempelai atau melalui pendampingnya yang berakhir dengan permintaan dari mempelai wanita agar mempelai pria mengucapkan do'a atau Pembacaan Syahadat. Dalam syair, terkandung janji setia. Setelah upacara buka pintu selesai mempelai pria diperbolehkan masuk ke dalam rumah.

\section{d. Upacara Munjungan (Berkunjung)}

Usai acara muka panto dilanjutkan dengan cara munjungan. Kedua mempelai bersujud sungkem kepada kedua orang tua mereka, sesepuh, kerabat dekat, dan kuncen. Akhirnya selesailah rangkaian upacara perkawinan di atas. Sebagai ungkapan rasa terima kasih kepada para undangan, tuan rumah membagikan makanan kepada mereka. Masing- masing mendapatkan boboko (bakul) yang berisi nasi dengan lauk pakunya dan rigen yang berisi opak, wajit, rangginang, dan pisang. Upacara Munjungan biasanya dilaksanakan selama seminggu. Beberapa hari setelah perkawinan, kedua mempelai wajib berkunjung kepada saudara saudaranya, baik dari pihak laki - laki maupun dari pihak perempuan. Maksudnya untuk menyampaikan ucapan terima kasih atas bantuan mereka selama acara perkawinan yang telah lalu. Biasanya sambil berkunjung kedua mempelai membawa nasi dengan lauk pakunya. Usai beramah-tamah, ketika kedua mempelai berpamitan akan pulang, maka pihak keluarga yang dikunjungi memberikan hadiah seperti peralatan untuk keperluan rumah tangga mereka.

\section{Makna yang terkandung dalam simbol- simbol upacara perkawinan Sunda di wilayah Kabupaten Kuningan}

Setiap bangsa atau suku bangsa memiliki kebudayaan sendiri - sendiri yang berbeda dengan kebudayaan bangsa lainnya, demikian juga dengan Kabupaten Kuningan. Kabupaten Kuningan memiliki kebudayaan yang khas yang dalam sistem budayanya digunakan simbol atau lambang - lambang sebagai sarana untuk menitipkan pesan pesan atau nasehat - nasehat bagi masyarakat pendukungnya. Dalam mengimplementasikan simbol, tidak terlepas dari sikap emosional dari seseorang dalam memahami simbol tersebut. Inti dari emosional keagamaan dipandang tidak dapat diekspresikan, karena hal itu merupakan pikiran - pikiran yang bersifat simbolik. Meskipun demikian, Simbolisme mempunyai potensi yang istimewa. Menurut Elizabeth (1994: 16) bahwa simbol - simbol secara emosional mampu membangkitkan perasaan dan ketentraman lebih dari pada sekedar formulasi verbal dari benda - benda yang mereka percayai sebagai simbol tersebut. Sampai sekarang, simbol merupakan pendorong yang kuat bagi timbulnya perasaan manusia untuk melakukan sesuatu.

Sejak zaman nenek moyang kita dulu, prosesi perkawinan ini diperlakukan sebagai suatu yang penuh dengan ritual dan syarat dengan simbol - simbol kehidupan dilihat dari kelengkapan-kelengkapan yang ada. Prosesi yang dilaksanakan dalam upacara perkawinan ini tidak hanya memuat sebuah rangkaian simbol - simbol tanpa makna (arti), tetapi merupakan suatu rangkaian yang mempunyai arti mendalam dan sering kali berkaitan dengan unsur - unsur religi.

Simbol - simbol dalam upacara yang diselenggarakan bertujuan sebagai sarana untuk menunjukkan secara semu maksud dan tujuan upacara yang dilakukan masyarakat pendukung. Dalam simbol tersebut juga terdapat misi luhur yang dapat dipergunakan untuk mempertahankan nilai budaya dengan cara melestarikannya. Adapun makna dari simbol - simbol yang ada dalam prosesi 
perkawinan adat Sunda di Kabupaten Kuningan.

\section{Upacara Ngeuyeuk seureuh}

Upacara ngeuyeuk seureuh ini lambang nasehat bagi anak laki - laki dan perempuan yang akan menjadi suami istri. Kata ngeuyeuk itu berpegang bersendi, maksudnya memberi tanda, bahwa ketika kedua orang telah berumahtangga, maka harus berpegangpegangan antara laki-laki dan perempuan, menunjukkan bahwa laki - laki bergantung pada perempuan dan sebaliknya bahwa perempuan bergantung pada laki - laki. Jadi artinya adalah jangan ada pertikaian, harus seia sekata dengan damai, hingga mencapai usia yang tinggi (Prawirasuganda, 1964: 76).

Adapun perlengkapan atau simbol simbol yang ada dalam upacara ini mengandung makna, yang diantaranya adalah sebagai berikut :

a. Ayakan, memberi petunjuk kepada kedua mempelai agar dalam melakukan sesuatu hal harus diayak terlebih dahulu baik - baik, diperhitungkan baik buruknya, dipertimbangkan dengan masak supaya tidak menghasilkan kekecewaan atau penyesalan.

b. Seureuh bertangkai, yang terdiri dari beberapa tangkai seureuh, melambangkan dua insan berlainan jenis yang bukan saudara sekandung.

c. Ramuan sirih seperti gambir, kapur sirih melambangkan kesatupaduan kedua insan.

d. Pakaian pengantin yang ditaruh diatas kepulan asap kemenyan itu melambangkan bahwa suami akan bertanggung jawab terhadap kebutuhan sandang istri, dan pada waktu upacara bisa berjalan dengan baik.

\section{Upacara Seserahan}

Adapun waktu pelaksanaannya bervariasi, ada yang melaksanakan satu minggu sebelum pelaksanaan aqad nikah, ada yang satu hari sebelumnya dan bahkan ada yang melaksanakannya pada hari pelaksanaannya aqad nikah. Maksud dari upacara ini adalah menyerahkan barang barang atau uang untuk membantu pelaksanaan upacara perkawinan. Disini terlihat adanya kerjasama antara pihak keluarga perempuan dengan pihak keluarga laki - laki, saling membantu upacara perkawinan. Islam juga memerintahkan manusia untuk saling membantu dan menolong sesama. Perlengkapan yang digunakan dalam upacara ini adalah sebagai berikut :

a. Uang sebagai lambang pengikat atau panyangcang, artinya tidak boleh lepas, tidak boleh ada yang mengganggu

b. Seperangkat perhiasan untuk lambang pengikat hubungan batin calon suami istri agar tidak berpaling pada orang lain. Selain itu merupakan hadiah pertunangan dan sebagai pernyataan kesungguhan tentang apa yang dijanjikan yaitu akan menikahi si gadis.

c. Peralatan dapur maksudnya jika nanti sudah berumah tangga sendiri, tidak sukar untuk mencarinya lagi.

\section{Upacara Sawer}

Syair/puisi sawer dalam upacara perkawinan adat Sunda bertujuan untuk menyampaikan pengajaran dan memberi nasihat tentang kehidupan Berumah tangga dan kehidupan bermasyarakat, sekaligus menggembirakan kedua mempelai yang sedang berbahagia. Karena itu, selain syair syairnya penuh dengan nasihat hidup, barang - barang yang disawerkan mempunyai makna. Adapun makna simbol dari alat - alat atau bahan - bahan dalam upacara sawer adalah sebagai berikut:

a. Beras putih sebagai simbol yang mempunyai makna bekal pokok kehidupan bahagia.

b. Kunyit sebagai simbol yang mempunyai makna agar mereka bersikap jujur kepada masing - masing pihak.

c. Bermacam - macam bunga rampai sebagai simbol yang mempunyai makna keharuman nama baik rumah tangga.

d. Uang logam sebagai simbol yang mempunyai makna kekayaan/ kecukupan.

e. Payung sebagai simbol yang mempunyai makna pelindung dalam menjalani hidup, keduanya harus bersikap hati - hati atau waspada, karena godaan bisa datang dari mana saja dan kapan saja. Selain itu suami berkewajiban menjadi pelindung untuk istri dan anak - anaknya kelak. 
f. Permen sebagai simbol yang mempunyai makna ramah tamah dan manis budi.

Makna dari penaburan dalam upacara sawer tersebut bukan membuang bahan bahan secara percuma tetapi sebagai petunjuk kepada kedua mempelai, bahwa bila dikemudian hari hidup senang, mulia dan bahagia, haruslah senang menolong dan membantu sesama dengan sedekah.

\section{Upacara Nincak Endog (Injak Telur)}

Upacara ini dimaksudkan untuk melambangkan suami istri. Istri harus rela melayani suami sedangkan suami memenuhi kewajibannya memberikan nafkah baik lahir maupun batin. Bahan - bahan/alat-alat yang digunakan dalam upacara nincak endog mengandung arti sebagai simbol dan nasihat untuk keselamatan kedua mempelai. Bahanbahan tersebut terdiri dari :

a. Telur ayam dipecahkan melambangkan kerelaan pengantin wanita dipecahkan kegadisannya, karena sudah menjadi kodrat seorang istri melayani suaminya. Disamping itu memberikan isyarat juga bahwa buah pergaulan suami istri akan menghasilkan keturunan berupa lendir yang menyerupai telur itu. Manusia lahir dari bahan yang sama, maka oleh karena itu, tidak ada alasan sama sekali seseorang untuk merasa angkuh, sombong dan merasa lebih dari yang lain.

b. Air bening dalam kendi kecil, mempunyai makna sebagai alat pembersih dan sebagai pendinginan atau penentraman suasana. Ada satu isyarat pula bahwa istri akan sangat senang selagi melayani suaminya, asalkan suami ketika akan masuk ke dalam rumah membawa hati yang bersih, jernih dan segar.

c. Lilin/Pelita mempunyai makna simbol sebagai penerang bagi kedua mempelai dalam menjalankan rumah tangga, agar keduanya saling asah, asuh, asih.

d. Kendi yang dipecahkan adalah menyatakan kepuasan hati.

e. Papan atau injakan, disimbolkan istri harus menuruti bimbingan suami.

\section{Upacara Buka Pintu}

Adapun maksud yang terkandung dari upacara buka pintu ini adalah menyatakan bahwa istri yang selalu berada di rumah harus dengan sabar menunggu suami pulang, dan suami juga ketika hendak masuk rumah harus memberi salam atau mengetuk pintu terlebih dahulu. Dalam upacara ini juga mempunyai makna sebagai pembelajaran kepada pengantin dalam hal tata krama di rumah antara suami dan istri, dan diajarkan bagaimana seharusnya istri menerima suaminya yang baru datang dan bagaimana seharusnya suami jika masuk rumah.

\section{Upaya masyarakat di wilayah Kabupaten Kuningan mempertahankan tradisi ritual adat sunda dalam upacara perkawinan}

Tradisi merupakan unsur esensial dari kehidupan masyarakat. Berbagai aktivitas kehidupan sehari - hari dilakukan menurut tradisi yang telah berlangsung turun temurun, sehingga tradisi itu telah mempranata dalam kehidupan masyarakat yang bersangkutan. Demikian halnya yang dilakukan oleh masyarakat Kabupaten Kuningan baik yang tinggal di Kabupaten Kuningan maupun yang tinggal di luar Kabupaten Kuningan merupakan tanah warisan leluhur mereka untuk anak cucunya, sehingga mereka berkewajiban untuk menjaganya. Hal ini tercermin baik dalam perilaku sehari - hari maupun dalam upacara - upacara ritual yang diselenggarakan secara tetap.

Tradisi dapat diartikan serangkaian pola perilaku yang dinilai tinggi, yang telah diwariskan secara turun temurun dari satu generasi ke generasi selanjutnya. Kapatuhan dan komitmen masyarakat Kabupaten Kuningan terhadap adat dan tradisi tersebut memang bukan tanpa alasan. Ada faktor yang menyebabkan masyarakat Kabupaten Kuningan masih mempertahankan tradisi ritual adat, pertama dalam falsafah hidup mereka dikenal ungkapan atau sebuah pepatah yang dijadikan pegangan oleh masyarakat Kabupaten Kuningan yang berbunyi, amanat, wasiat, dan akibat. Maksudnya apabila amanat dan wasiat dari orang tua dan para leluhur dilanggar, maka niscaya akan membawa akibat, baik kepada diri sendiri maupun keluarga dan lingkungannya. Kedua, karena masyarakat Kabupaten Kuningan mempunyai tingkat solidaritas yang sangat tinggi, seperti tradisi ini tidak luntur dan tetap dijalankan. 
Ketiga, masyarakat di Kabupaten Kuningan mempunyai tingkat pendidikan yang relatif rendah, maksudnya pola pikir masyarakatnya masih murni dan belum terkontaminasi oleh dunia luar sehingga tradisi ini masih ada. Pepatah inilah yang senantiasa dipedomani oleh masyarakat di Kabupaten Kuningan, sehingga mereka begitu patuh terhadap pantangan - pantangan yang diberlakukan kepada mereka. Selain itu, adat dan tradisi ritual dalam setiap upacara itu sudah ada sejak dulu dari nenek moyang mereka. kendati orang - orang tua tidak pernah memberikan penjelasan yang detail mengenai sesuatu hal yang berkenaan dengan adat - istiadat, baik berupa pantangan maupun bentuk - bentuk adat istiadat lainnya kepada generasi selanjutnya, akan tetapi tradisi - tradisi itu tetap terpelihara.

\section{KESIMPULAN}

\section{Simpulan}

Masyarakat desa yang ada di Kabupaten Kuningan memiliki karakteristik yang unik yang tercermin dari kebudayaan yang dimilikinya baik dari segi agama, bahasa, kesenian, adat istiadat, mata pencaharian, dan lain sebagainya. Tujuan Perkawinan merupakan sifat atau tabiat manusia yang cenderung untuk mengadakan hubungan sesama manusia. Allah Swt telah menjadikan hubungan perkawinan sebagai Sunnah para Rasul dimana ia akan melahirkan rasa saling cinta, sikap saling bekerjasama dengan kebaikan dan bantu membantu untuk mendidik keturunan. Melalui perkawinan juga, manusia akan dapat mengembangkan keturunan dan memenuhi ketenteraman jiwa karena perkawinan yang harmoni dan sesuai menurut tuntutan Ilahi sebagai tempat untuk bersehat jasmani maupun rohani. Perkawinan merupakan peristiwa bersejarah di mana ia tak mudah dilupakan bagi orang-orang beriman.

Faktor yang menyebabkan masyarakat Kabupaten Kuningan masih mempertahankan tradisi ritual adat antara lain karena masyarakat Kabupaten Kuningan mempunyai tingkat solidaritas yang sangat tinggi, seperti dalam setiap upacara mereka selalu saling membantu dan tolong menolong sehingga tradisi ini tidak luntur dan tetap dijalankan. Salah satu unsur budaya yang masih diakui keberadaannya dan dianggap sebagai warisan budaya yang penting dalam perjalanan hidup setiap orang adalah upacara perkawinan adat. Seperti upacara perkawinan adat Sunda khususnya pada masyarakat Kabupaten Kuningan dalam prosesi perkawinan adat terdapat kepercayaan dan keyakinan terhadap ritual perkawinan yang diwariskan para leluhur, jika secara esensial diwarnai dengan ajaran - ajaran Islam. Oleh karena itu, perkawinan merupakan perpaduan antara nilai adat istiadat masyarakat, ajaran agama dan undang - undang yang telah ditetapkan pemerintah Indonesia. Adapun prosesi upacaranya adalah sebagai berikut: a)Tahap pra perkawinan; melamar, ngeuyeuk seureuh, dan seserahan, b)Tahap perkawinan; akad nikah dan sungkem, c)Pasca perkawinan; upacara sawer, nincak endog, muka panto, dan munjungan; banyak mengandung maksud, pesan dan harapan yang bermanfaat untuk kedua calon pengantin yang akan menjalani kehidupan berumahtangga.

\section{DAFTAR PUSTAKA}

Ahmad Azhar Basyir. 1999. Hukum Perkawinan Islam. Yogyakarta : UII Press.

Heni Fajria Rif'ati dkk. 2002. Kampung Adat dan Rumah Adat di Jawa Barat. Dinas Kebudayaan dan Pariwisata Propinsi Jawa Barat.

Hilman Hadi Kusuma. 1990. Hukum Perkawinan Adat. Bandung : Citra Aditya Bakti.

Kamal Mukhtar. 1993. Asas - Asas Hukum Islam tentang Perkawinan. Jakarta : Bulan Bintang.

Musa Asy'ari. 1992. Manusia Pembentuk Kebudayaan Dalam Al-Qur'an . Yogyakarta: LESFI.

Prawirasuganda. 1964. Upacara Adat di Pasundan. Bandung : Sumur Bandung.

Thomas Wiyasa Bratawidjaja. 1990. Upacara Perkawinan Adat Sunda. Jakarta : Pustaka Sinar Harapan.

Wawancara dan observasi dengan Tokoh Agama, Tokoh Masyarakat/ Budayawan, dan Anggota Masysrakat yang ada di beberapa desa di Kabupaten Kuningan. 


\section{LAMPIRAN}

\section{Prosesi Lamaran}

a. Nenden omong

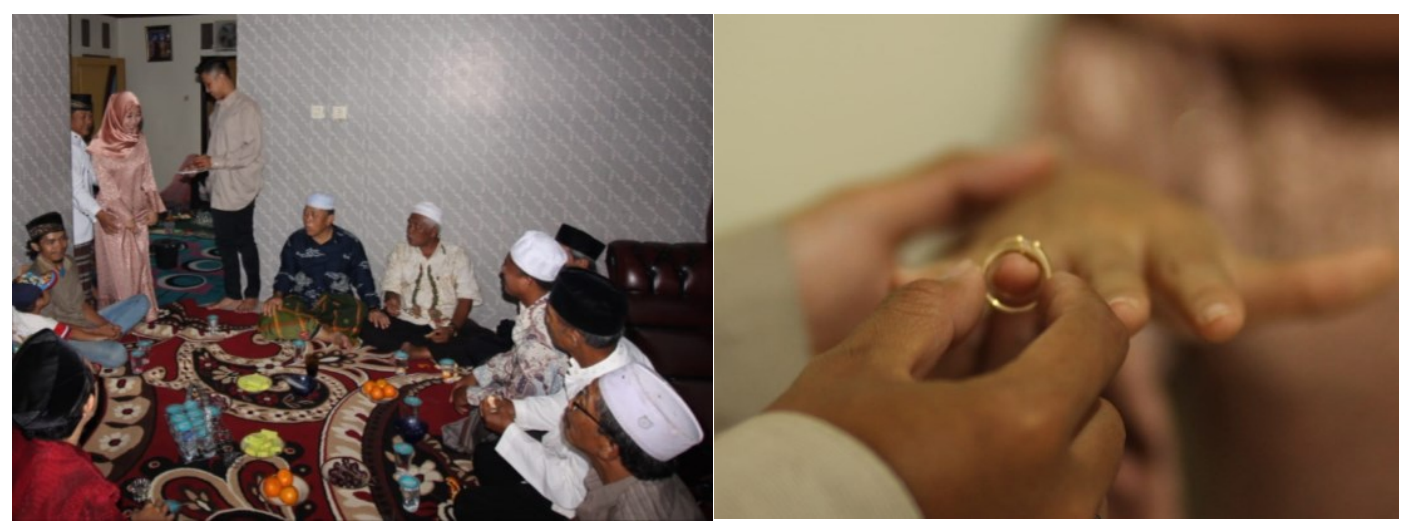

\section{Prosesi Pernikahan}

a. Upacara Seserahan

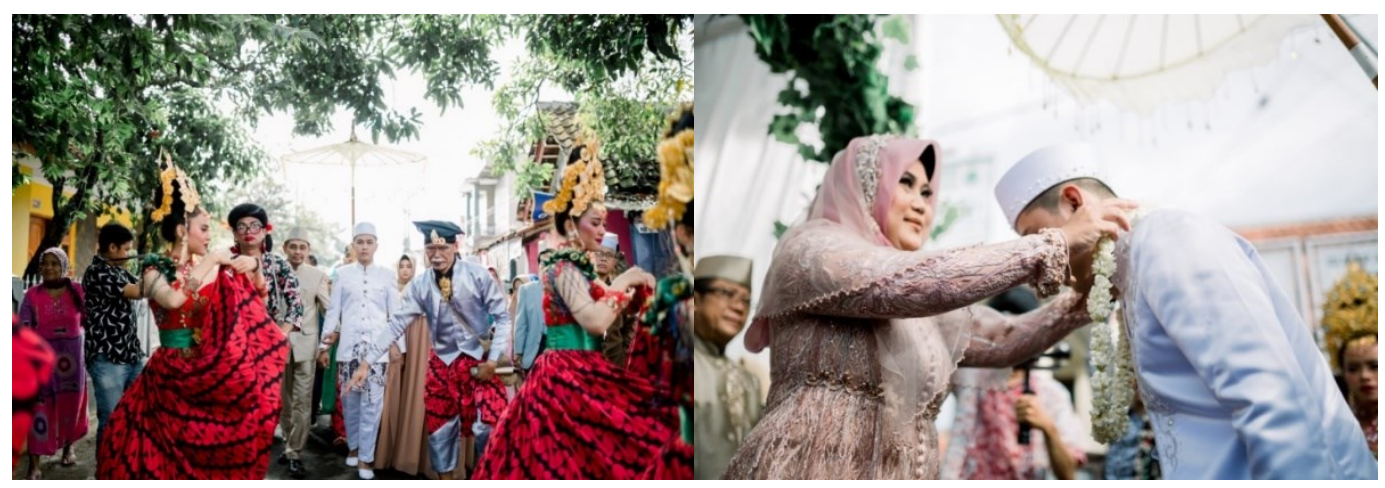

b. Upacara Aqad Nikah

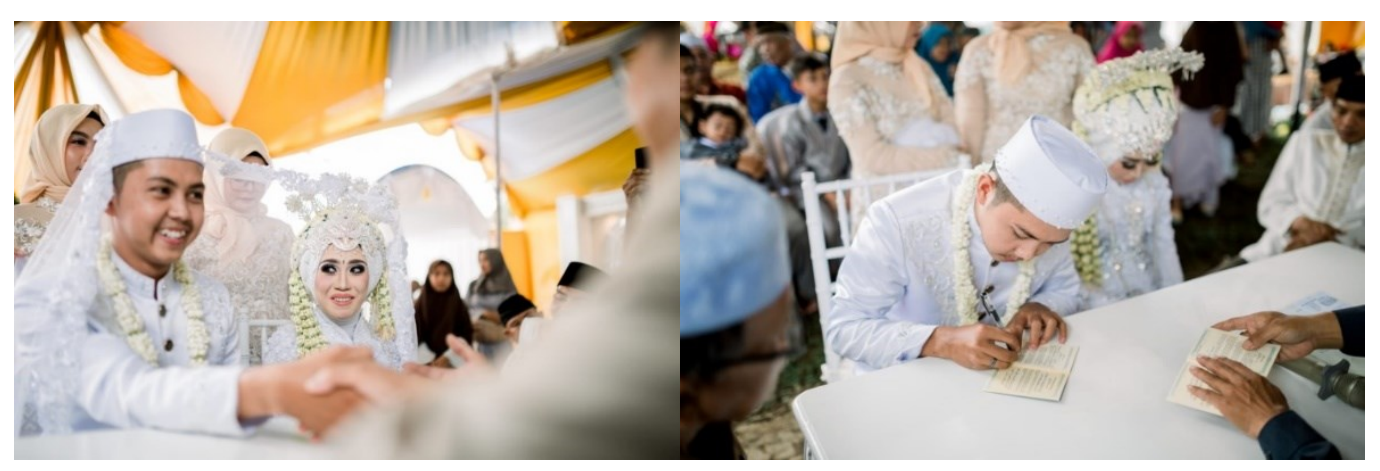




\section{c. Sungkem}

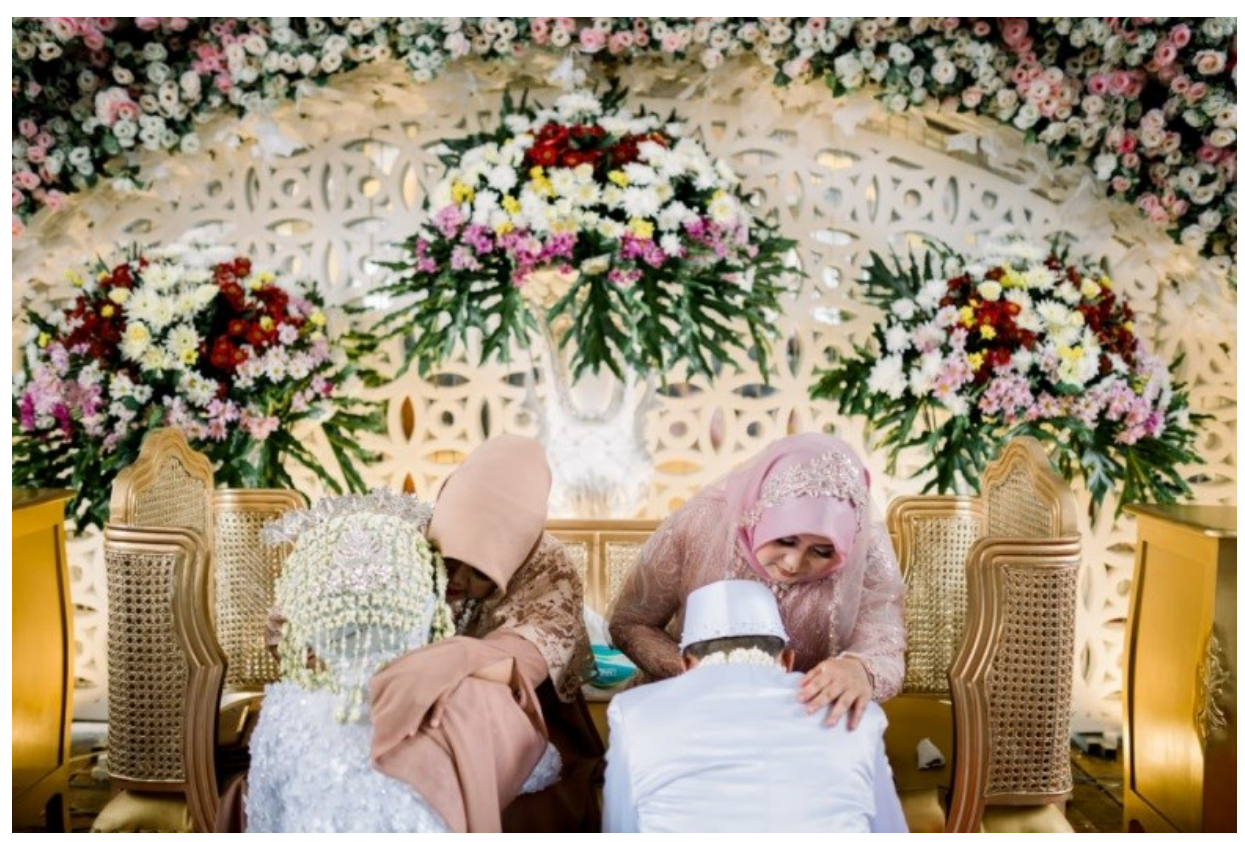

\section{Prosesi Setelah Pernikahan}

a. Sawer pengantin

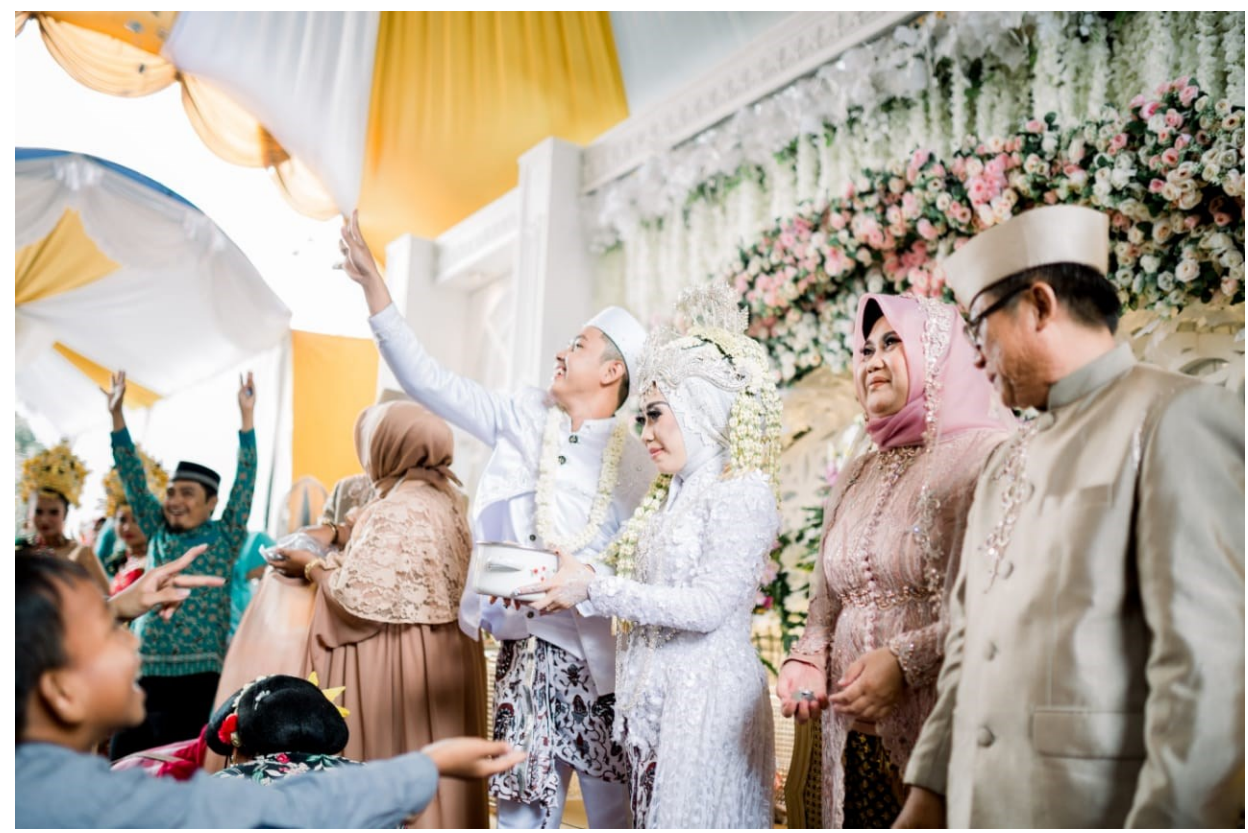




\section{b. Upacara Nincak endog}

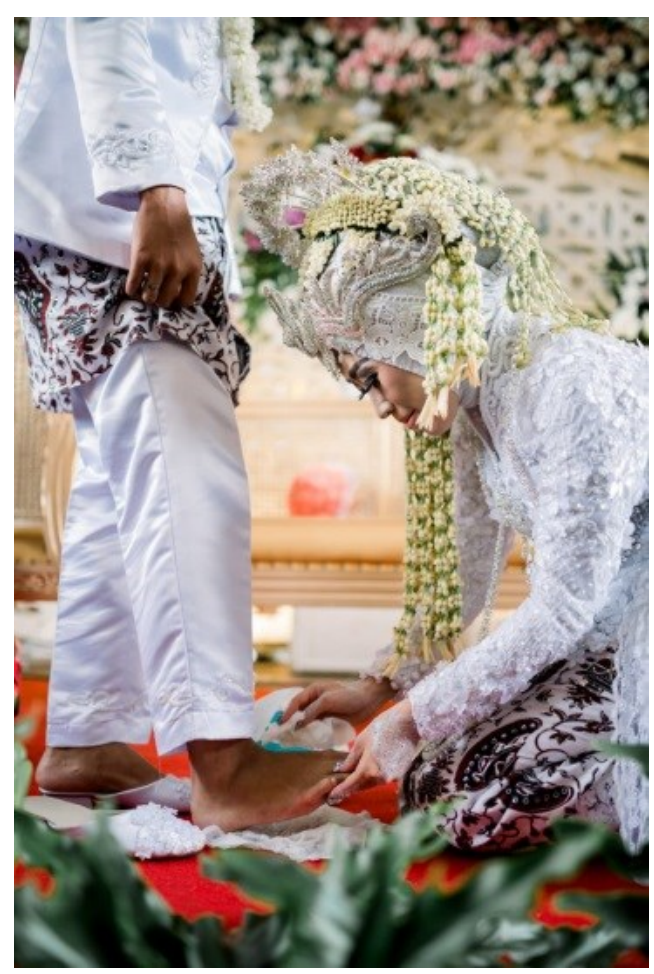

